\title{
European fuel economy policy for new passenger cars: a historical comparative analysis of discourses and change factors
}

\author{
Takahiro Oki ${ }^{1}$ (D)
}

Accepted: 25 September 2020 / Published online: 9 October 2020

(C) The Author(s) 2020

\begin{abstract}
In April 2019, the European Union (EU) revised its fuel economy policy for new passenger cars (PC). The new standard set an ambitious policy framework that featured high $\mathrm{CO}_{2}$ caps on these vehicles from 2025 and 2030 with limited flexibility for automobile industry to comply with the new standard, reflecting European decision-makers' aspirations for zero-emission mobility. Most literature on EU policy-making and interest representation has pointed out the power of automobile industry and argued that these industry actors were able to influence the stringency of actual emission standards in the timeframe of 2012 and 2020. However, this conventional view of the dominance of automobile industry does not sufficiently explain why European policy-makers were able to change their fuel economy policy so significantly in 2019. To fill this research gap in the existing literature, this research focuses on discourses and coalitions of actors who deployed these discourses throughout three legislative processes that have shaped the EU's fuel economy policy: Regulation 443/2009, Regulation 2014/333 and Regulation 2019/613. This research not only considers the interests and powers of relevant actors, which are the primary focus of much of the existing literature; but also a range of ideas and discourses that they have brought to policy discussions. Drawing on the theoretical literature of argumentative discourse analysis (ADA) and policy change, this article attempts to highlight discursive battles within key actors over the stringency of EU's fuel economy policy on PCs.
\end{abstract}

Keywords Fuel economy $\cdot$ Passenger cars (PC) $\cdot$ Discourse change $\cdot$ Multi-level governance $\cdot$ European Union

\section{Introduction}

Why were European policy-makers able to change their fuel economy policy so significantly in 2019, and not before? Much of the literature on EU policy-making and interest representation point out the power of business actors and their capability to significantly influence policy-making processes (e.g., Crombez 2002; Eising 2007), particularly

Takahiro Oki

1 Bavarian School of Public Policy, Technische Universitat Munchen, Munchen, Germany 
the automobile industry (e.g., Haas and Sander 2019; Katzemich 2018; Marshall 2015; Nowack and Stemkopf 2015). This conventional view of European policy-making does not sufficiently answer this research question. This research, therefore, looks into not only the interests and power of these actors, but also the role and power of discourses that they have deployed in a range of policy debates. To do so, this article traces legislative processes of the EU's $\mathrm{CO}_{2}$ emission standards for PC over the last decade in a comparative manner as none of the existing literature has sufficiently compared these three legislative processes with a focus on discourses.

Drawing on post-structuralist discourse analysis (e.g., Fischer 2003; Hajer 1995, 2006; Howarth 2002), this research aims to illuminate discursive battles between the following two competing discourses coalitions, defined as the ensemble of storylines, actors and their practices (Hajer 1995, p. 60): socioeconomic discourse coalition, which advocated for a less stringent policy framework by emphasizing potential negative regulatory impacts on jobs and competitiveness; and the one which stressed the need to drive the car market toward low- and zero-emission mobility and asked for a more stringent framework with discourses. This article hypothesizes that the policy change in 2019 was due to change in dominant discourse and coalition within the community of fuel economy policy from socioeconomic to environment discourse coalition.

In addition, drawing on the theoretical perspective of multi-level governance (MLG), this article seeks to identify key change factors. This article argues that the combination of the following exogenous and endogenous factors ranging from international to European and national levels have influenced the discursive battles at the European level in favor of the environment discourse coalition: (1) the evolution of international climate norms and the EU's aspirations to remain a global leader; (2) declining presence of some key Member States in the socioeconomic discourse coalition; (3) the development of alternative vehicle technologies; and (4) declining influence of automobile industry lobbying. This research draws on qualitative data obtained from publicly available policy documents, complemented by the method of participant observation from my professional experience as an automobile industry representative during the policy-making process for the EU fuel economy policy throughout 2018 and 2019.

\section{Methodology}

Discourse is generally understood as "historically specific systems of meaning which form the identities of subjects and objects" (Howarth 2002, p. 9), considered as an ensemble of words and sentences where distinct ideas and social meanings are embedded. The argumentative discourse analysis (ADA) illuminates the process through which a certain discourse can structure the inter-subjective understandings of policy issues among relevant actors, including policy-makers and relevant stakeholders. Actors create their own storylines-a condensed sort of narrative that connects different discourses (Hajer 1995, p. $58 ; 2006$, p. 72) - and compete with other actors over the interpretation of the policy issues (Fischer 2003, p. 76). These storylines serve as the basis of discourse coalition, bringing together actors using similar storylines. These discourse coalitions mobilize their shared narratives and storylines at various policy fora in order to frame policy debates in line with the own social realities that they construct through their own interpretive lenses. The ultimate goal of these coalitions is to obtain a hegemonic status within a policy network by (re) structuring the widespread understanding of the issues (discourse structuration) and 
by having their discourse translated into institutional and policy arrangements (discourse institutionalization) (Hajer 1995, pp. 59-60).

The theoretical perspective of multi-level governance (MLG) considers the EU as a multi-layered system with multiple actors and factors operating at different levels of governance (i.e., national, regional or local) to pursue their interests (Hooghe and Marks 2001; Pollack 1997). This MLG perspective illuminates the role of policy network, a group of public and private actors with a high degree of functional segmentation and specialization across different levels of governance (i.e., Ansell 2000; Kohler-Koch 1997). The network is typically organized around Directorates General of the Commission (DGs), joined by relevant working groups at the Council, corresponding functional committees within the European Parliament (EP) and relevant stakeholders including non-governmental organizations (NGOs), business groups, researchers and consultants (Bouwen 2009, pp. 23-26; Kohler-Koch 1997, pp. 1-3). Thus, scholars with the MLG approach seek to identify key actors and factors with relevant policy networks across different levels of governance to explain a policy change at the European level.

This article systematically compares three historical processes leading to the following European regulations on $\mathrm{CO}_{2}$ emissions standards for PCs: Regulation 443/2009 (Case 1); Regulation 2014/333 (Case 2); and Regulation 2019/613 (Case 3). The decision-making processes of these three regulations took place under the same legal and institutional rules named ordinary legislative procedure (OLP). ${ }^{1}$ Therefore, a historical comparison of these three regulations helps minimize legal and institutional influence on policy outcomes, and aims to single out relevant explanatory variables and processes behind the policy change in Case 3 through this historical comparative analysis with the most similar cases (George and Bennett 2005 p. 81; Mahoney and Rueschemeyer 2003; Mahoney 2004). This comparative analysis relies on an extensive literature review (i.e., legislative texts, policy papers and web articles) and process tracing of the decision-making processes as well as the method of participant observation tied to my professional experience as an industrial representative in Case $3^{2}$ as a supportive method to complement the documentary analysis.

The article looks into the storylines that these actors deployed at various policy fora and group them into either environment discourse coalition or socioeconomic discourse coalition: the former is defined as a group of actors who deployed a range of environmental narratives and storylines to frame the issue of fuel economy; and the latter as a group of actors who attempted to frame the issue of fuel economy as a matter of job creation and industry competitiveness, asking for less stringent and more flexible fuel policy framework This discourse analysis focuses on discursive battles over the most controversial issues, such as the level of $\mathrm{CO}_{2}$ caps expressed in corporate average and the introduction of flexibility mechanisms. This article investigates which of the two competing discourse coalitions structured the inter-subjective understanding within the policy network and was able to have their discourse institutionalized in EU's fuel economy policy. Ultimately, this discourse analysis

\footnotetext{
1 A legislative process where the Council representing the interests of the EU Member States and the EP representing European citizens examines the Commission's legislative proposals (Article 294 of the Treaty of Functioning of the European Union).

2 The author was employed by Nissan Motor Corporation, a Japanese car manufacturer for the period between July 2017 and March 2019. During this period, the author was directly involved in the policymaking process of as an industry representative and participated in meetings with European Commission, European Parliament and several Member States on a variety of issues of EU's fuel economy policy.
} 
aims at verifying whether there was a change in the dominant discourse from socioeconomic to environment discourse coalition over time.

In addition, this article seeks to verify what factors have triggered this discourse change with a particular focus on the following four variables: (1) normative influence from the evolution of international climate negotiations and the EU's aspirations to remain a global leader as a potential exogenous change factor empowering the legitimacy of environment discourse; (2) declining presence of the Member States in socioeconomic discourse coalition during discursive battles; (3) the development of cost-effective alternative vehicle technologies, such as batteries; (4) change in the influence of automobile industry lobbying, potentially affected by recent scandals related to the Dieselgate.

\section{Historical comparison-the $\mathrm{EU} \mathrm{CO}_{2}$ emissions standard for $\mathrm{PCs}$}

\subsection{Emerging legislative approach}

In the late $2000 \mathrm{~s}$, the $\mathrm{CO}_{2}$ emissions from transport were becoming a common concern among European policy-makers, as the EU aspired to become and remain a global leader in climate action (e.g., Oberthür and Kelly 2008). The Kyoto Protocol entered into force in 2005 and its first commitment period was about to begin. In addition, many countries were discussing an action plan for the period after the expiration of the Kyoto Protocol in 2012 as part of the UN Framework Convention on Climate Change (UNFCCC) (Moosman et al. 2019). In this context, there was a rising recognition across European institutions that the voluntary approach alone would not suffice to reach the $2012 \mathrm{CO}_{2}$ target and mandatory approach is needed instead. In this context, the Commission published a communicationA Competitive Automotive Regulatory Framework for the 21st Century-in February 2007. It proposed an integrated approach consisting of mandatory $\mathrm{CO}_{2}$ emissions standard with an objective of $130 \mathrm{~g} / \mathrm{km}$ in corporate average by 2012 and a set of complementary technological measures aiming at an additional reduction of $10 \mathrm{CO}_{2} \mathrm{~g} / \mathrm{km}$ (i.e., efficient mobile air conditioners, tire pressure monitoring, gearshift indicators and bio fuels; EC 2007a, p. 10). Having obtained wide support from the public hearing organized in July 2007, the Commission put forward a legislative proposal in December 2007 with a $2012 \mathrm{CO}_{2}$ cap of $130 \mathrm{~g} / \mathrm{km}$ and flexibility provisions to mitigate regulatory impacts on automobile industry (EC 2007b).

Several actors deployed environmental storylines at multiple policy fora within the European Parliament (EP) and the Council of the EU (Council): the Committee on Environment, Public Health and Food Safety (ENVI) acting as the Committee Responsible within the EP, the Netherlands, Belgium, Sweden, Finland, Denmark and environmental NGOs Transport \& Environment (T\&E), Greenpeace and Friends of the Earth Europe. They emphasized the EU's global climate leadership and the need to align the $\mathrm{CO}_{2}$ emissions standard with its international commitments to climate action (Council 2008a). This environment discourse coalition-the ensemble of the environment actors, green storylines and common discursive practices - strongly advocated for a more stringent design of the $\mathrm{CO}_{2}$ standard than the Commission's initial proposal, notably the introduction of a longterm $\mathrm{CO}_{2}$ objective with maximum of $95 \mathrm{~g} / \mathrm{km}$ and elimination of flexibility mechanisms (EP 2008a).

Other actors employed the storylines of negative socioeconomic impacts throughout the policy debates: a few Member States with domestic automobile industry, such as Germany, 
France, the UK and Italy; the Committee on Industry, Research and Energy (ITRE) acting as the Committee for Opinion within the EP; and automobile industry and associations, such as European Automobile Manufacturers' Association (ACEA) and German Association of the Automotive Industry (VDA). These actors stressed too stringent policy design would hamper technology innovation, damage industry competitiveness and imperil job security. They strongly advocated for the introduction of a phase-in system that would push back the full compliance of the $2012 \mathrm{CO}_{2}$ caps until 2015, reduction of penalties and rejection of a longer-term objective for 2020 (EP 2008b).

Within the EP, the ITRE voted on 3 September 2008 in favor of a set of amendments reflecting the concerns about socioeconomic impacts, which were then transferred to the ENVI for its own vote on 25 September. Before the vote, the rapporteurs ${ }^{3}$ of ENVI and ITRE-Italian socialist Guido Sacconi and German Christian Democrat Werner Langenprepared a set of compromise provisions. They favorably considered the socioeconomic discourse, including the introduction of the phase-in system as well as a super-credit system as an additional flexibility mechanism that would allow manufacturers to multiply the counting of cars emitting less than $50 \mathrm{~g} / \mathrm{km}$ in their total $\mathrm{CO}_{2}$ compliance. However, their compromise proposals did not pass at the ENVI vote, and the ENVI adopted stringent provisions that reflected the environment discourse (EURACTIV 2008d).

On the Council side, the French Presidency prepared a compromise text for the Environment Council meeting in October 2008. This compromise integrated the propositions that the socioeconomic discourse coalition advocated for, such as the phase-in mechanism and the super-credit system. Germany led by Christian Democrat Chancellor Angela Merkel, France by Republican President Nicola Sarkozy and Italy by Central Left Prime Minister Berlusconi played a key role in forging a consensus within the Council on these flexibility mechanisms. Inter-institutional negotiation among the Council, the EP and the Commission (Trilogue) was launched in November 2008 to seek a compromise across the EU institutions about the policy design of the $\mathrm{CO}_{2}$ standard. While the environmental coalition was able to secure the introduction a longer-term objective of $95 \mathrm{~g} \mathrm{CO}_{2} / \mathrm{km}$ toward 2020 , the final political deal that reached on 1 December 2008 reflected the socioeconomic discourse as it institutionalized the flexibility mechanisms and delayed the $\mathrm{CO}_{2}$ emissions limits with lower penalties (EURACTIV 2008b).

\subsection{Setting modalities for the $2020 \mathrm{CO}_{2}$ target}

The early 2010s saw rising political interest in the issue of decarbonization. At the international level, the EU was actively engaging in global climate negotiations under the UNFCCC despite the 2009 failure at COP 15 in Copenhagen to agree on binding commitments after the Kyoto Protocol, which resulted in the 2012 agreement on the extension of the expiring Kyoto Protocol (Moosman et al. 2019). At the European level, the Commission published a communication in March 2011-a low-carbon roadmap toward 2050, which stipulated a Europe-wide long-term vision of reducing GHG emissions by $80-95 \%$ toward 2050 with a sectoral target of $60 \%$ cut from transport compared to its 1990 level. Road transport was one of the few sectors with limited progress in

\footnotetext{
3 Parliamentary committee nominates one of its members as rapporteur who drafts a committee report on the subject and negotiate with representatives of the other political parties (shadow-rapporteurs) within the committee to forge a consensus (Corbett et al. 2011, p. 158).
} 
$\mathrm{CO}_{2}$ emissions abatement, accounting for a 26\% increase between 1990 and 2008 (EC 2012 , p. 2). It was in this political climate that the Commission put forward a legislative proposal in July 2012 to set the modalities for the compliance with the $\mathrm{CO}_{2}$ cap in 2020 (EC 2012).

A group of environmental actors mobilized similar storylines throughout the policy debates, stressing the future path of decarbonization and the need for clean and zeroemission mobility (EP 2013). These actors included the ENVI, several Member States, such as northern European countries and the Netherlands, and environment NGOs as well as the ITRE and TRAN, which were previously not part of this environment discourse coalition. This coalition strived to push for a more stringent framework than the Commission's proposal. They objected the reintroduction of the super-credit system for the period after 2020 as a potential watering down of the $2020 \mathrm{CO}_{2}$ cap (Hall 2012), and argued for the introduction of a tighter $\mathrm{CO}_{2}$ cap for beyond 2020 and a mandate to introduce certain number of low- and zero-emission vehicles (EP 2013, p. 32). Another group of actors advocated for greater flexibility for automobile industry to meet their 2020 targets. They included Germany, France, Italy, the UK and Spain, joined by automobile industry associations. This socioeconomic discourse coalition employed storylines built upon industrial competitiveness and social impacts of strict modalities for the $2020 \mathrm{CO}_{2}$ cap (Hall 2012).

In April 2013, the ENVI adopted its first Committee report, which included an indicative $\mathrm{CO}_{2}$ target in the range of $68-78 \mathrm{~g} \mathrm{CO}_{2} / \mathrm{km}$ toward 2025 while compromising with the socioeconomic discourse coalition by accepting the introduction of the super-credit system with a cap of $2.5 \mathrm{~g} \mathrm{CO}_{2} / \mathrm{km}$ per year until 2023 (EP 2013). On the Council side, the Member States agreed on its common approach, which reflected the propositions that the socioeconomic discourse advocated for as it rejected the long-term $\mathrm{CO}_{2}$ cap beyond 2020 while keeping the super-credit mechanism. The EP, the Council and the Commission launched Trilogue negotiations in late May under the Irish Presidency and reached a compromise at their third informal Trilogue meeting on 24 June. The final deal had the super-credit system with a cap of $2.5 \mathrm{~g} \mathrm{CO}_{2} / \mathrm{km}$ per/year from 2020 to 2022 with the emission thresholds raised from the Commission's initial proposal of $35 \mathrm{~g} \mathrm{CO}_{2} / \mathrm{km}$ to $50 \mathrm{~g} \mathrm{CO}_{2} / \mathrm{km}$, while rejecting to have any longer-term vision or objectives (Council 2013).

However, the official vote expected on 25 June was postponed due to the pressure from several Member States, Germany, Poland, the UK and France, which were concerned about potential negative impacts on their automobile industry. The German government led by Chancellor Merkel played a pivotal role in convincing the other countries of the need to delay the vote and in creating pressure on the Irish Presidency. Germany advocated for an additional flexibility scheme to mitigate regulatory impact on German automobile industry with heavier premium car segments. Germany proposed a 4-year phase-in period at the Competition Council on 27 September, aiming at shifting the year of full compliance with the $2020 \mathrm{CO}_{2}$ cap to 2024 (Neslen 2013).

On 14 October, the Member States formally agreed to reopen the discussion, and the Lithuanian Presidency started to redraft a compromise text for an eventual inter-institutional agreement among the three European institutions. A new compromise was reached on 26 November 2013 in favor of the socioeconomic discourse as it institutionalized a phase-in system for the year 2020, requiring manufacturers to comply only $95 \%$ of their new car sales with $95 \mathrm{~g} \mathrm{CO}_{2} / \mathrm{km}$ in 2020 and $100 \%$ only in 2021 . It also modified the supercredit system with a cap of $7.5 \mathrm{~g} \mathrm{CO}_{2} / \mathrm{km}$ for the years 2020-2022, allowing manufacturers to use all the flexibility in the first year, significantly lowering the actual stringency of the $2020 \mathrm{CO}_{2}$ cap (Council 2013). 


\subsection{Post $2020 \mathrm{CO}_{2}$ standards}

Toward the mid-2010s, the EU was at the forefront of global efforts to tackle climate change. In October 2014, the EU announced its 2030 climate and energy framework and set a -40\% target of GHG emissions reduction compared to its 1990 level. It was aimed at facilitating the global climate negotiations and brokering an ambitious agreement in the lead up to the 2015 COP 21 in Paris However, it became clear that transport was still lagging behind the EU's effort for decarbonization despite a series of actions taken over the last few decades. Road transport was responsible for around $20 \%$ of the EU's total GHG emissions in 2015, representing 78\% of the EU's oil consumption (Erbach 2019, p. 2).

In November 2017, the Commission launchedClean Mobility Package. It was a call for a wide range of initiatives and policy measures aimed at the uptake of low- and zero-emissions vehicles in the context of the 2030 climate and energy targets and the EU's commitment to the Paris Agreement. This package included a proposal for new $\mathrm{CO}_{2}$ targets on PCs beyond 2020 with a $\mathrm{CO}_{2}$ limit of $-15 \%$ in 2025 and $-30 \%$ in 2030 compared with the 2021 level based on a new emission measurement method. ${ }^{4}$ The Commission also proposed to replace the current flexibility schemes with a new incentive mechanism that rewards manufacturers whose sales share of low- and zero-emission vehicles (LEV/ZEV) exceed the proposed benchmark levels of $15 \%$ in 2025 and $30 \%$ in 2030 by easing their $\mathrm{CO}_{2}$ targets (EC 2017).

A large number of actors deployed environmental storylines stressing the need for alignment with the 2015 Paris Agreement: the ENVI, the TRAN and the ITRE of the EP; numerous Member States, including Luxembourg, Austria, Belgium, the Netherlands, Portugal, Ireland, Slovenia as well as France, Italy and Spain which previously took the side of socioeconomic discourse coalition; and environment NGOs. This environment discourse coalition argued for a more stringent policy design than the Commission's proposal, including tighter $\mathrm{CO}_{2}$ caps for 2025 ranging from $-25 \%$ to $-5 \%$ and for 2030 between $-40 \%$ and $-75 \%$ as well as a stronger penalty system that would punish manufacturers not reaching the ZLEV benchmark (EP 2018). Socioeconomic discourse coalition, which strived for a less stringent policy arrangement than the initial proposal from the Commission, included Germany and several East European countries (i.e., Hungary, Poland and Czech Republic) joined by automotive associations. By employing the storylines of negative regulatory impacts on jobs and competitiveness, they advocated for lower $\mathrm{CO}_{2}$ cap toward 2030 than $-30 \%$ (Council 2018).

Following the Committee vote on the draft report at the ENVI on 10 September, the EP's Plenary vote was held on 3 October. The EP's decision largely reflected the environment discourse, asking for a $-40 \% \mathrm{CO}_{2}$ emissions reduction by 2030 with an intermediate target of $-25 \%$ by 2025 . The EP also supported a more limited incentive scheme by raising the benchmarks to $20 \%$ by 2025 and $35 \%$ by 2030 with severe penalties for the manufacturers not reaching these benchmarks (EP 2018b). On the Council side, there were divided views until early October. It was on 9 October when Member States managed to adopt its general approach at an Environment Council meeting, which reflected propositions of environment discourse: the approach put forward $\mathrm{CO}_{2}$ targets of $-15 \%$ by 2025 and $-35 \%$ by

\footnotetext{
4 The New European Driving Cycle (NEDC) received criticism regarding its effectiveness in measuring $\mathrm{CO}_{2}$ emissions due to the flexibilities that it gave to carmakers when undertaking the emission tests. The Worldwide Harmonized Light Vehicles Test Procedure (WLTP) was developed as a new global standard to address this issue with more robust testing conditions (Tsiakmakis et al. 2017).
} 
2030 with the same thresholds for the benchmarks of the ZLEV scheme while adopting a more favorable accounting of the introduction of ZLEV in countries with a limited share of such vehicles (Council 2018).

Trilogue negotiations started on 10 October 2018 and intense political debates took place throughout November and December between two competing discourses across the institutions. A final compromise was reached at the fifth Trilogue meeting held on 17 December 2018, which largely reflected what the environment discourse coalition wished for as they managed to secure, among others, a higher $\mathrm{CO}_{2}$ target toward 2030, a ZLEV incentive scheme with higher benchmarks and the introduction of a longer-term target toward 2040. The socioeconomic discourse coalition was only able to secure a favorable arrangement for the introduction of ZLEV in countries with less such vehicles (Erbach 2019).

\subsection{Change in dominant discourse and coalition}

The historical comparison of the three cases has shown that the history of the EU's $\mathrm{CO}_{2}$ emissions standard on PCs features discursive battles between two competing discourse coalitions over the stringency of policy design. By deploying their own storylines, these coalitions strived to frame the issue of vehicle's $\mathrm{CO}_{2}$ emissions through their own interpretive lenses. The environment discourse coalition emphasized the need to decarbonize the road sector to be in line with the EU's commitment to international climate agreements while the socioeconomic discourse coalition stressed negative regulatory impacts on jobs and competitiveness throughout the policy debates across the three cases.

This comparative analysis confirms the first hypothesis that dominant discourse within the policy network changed overtime, indicating that different discourses experienced the process of discourse institutionalization across the three cases. Policy arrangements strongly reflected the propositions of socioeconomic discourse in Case 1 and Case 2 and institutionalized a set of flexibility mechanisms, such as the phase-in systems and the super-credit systems. However, the final compromise in Case 3 mirrored the environment discourse with higher $\mathrm{CO}_{2}$ caps and ZLEV benchmarks as well as the introduction of an indicative target toward 2040. The socioeconomic discourse coalition could not succeed in securing their propositions, such as lower $\mathrm{CO}_{2}$ caps and greater flexibility.

Another observation that relates to the process of discourse structuration complements this first observation. Thus, the historical comparison indicates that different discourses structured the dominant way of framing the issue of vehicle's $\mathrm{CO}_{2}$ emissions at the end of each of the three legislative processes. This phenomenon can be observed in the narratives and languages used at the EP's Plenary sessions held before its formal votes on the final compromises across the three cases. In Case 1, the socioeconomic discourse largely featured the statements made by the rapporteurs of ENVI and ITRE as well as most of the shadow-rapporteurs during the Plenary session that took place on 16 December 2008. For example, the speech by socialist ENVI rapporteur Sacconi emphasized the need for greater flexibility for automobile industry y, which the ENVI initially fought against claiming it as a potential watering down as follows:

Finally, we have introduced greater flexibility, as I said, because, as we have managed to strengthen the regulation, it has been possible, reasonable and fair to allow businesses to take a gradual approach, phasing in the new measures between 2012 and 2015 (EP 2008c). 
Only a few MEPs from the European Green Party and the European United Left/Nordic Green Left (GUE/NGL) made statements in line with the environment discourse, signaling deep concerns about the level of ambition not meeting the EU's commitments to international climate agreement. GUE/NGL's shadow-rapporteur at ENVI Jens Holm stated, "What we are to vote on now is a lost opportunity. When this law comes into force in 2012, $35 \%$ of cars will be exempt" (EP 2008c).

In Case 2, the most controversial points were the re-introduction of flexibility mechanisms and the establishment of $\mathrm{CO}_{2}$ caps beyond 2020, and discursive battles ended in favor of the socioeconomic discourse coalition. Similar to Case 1, the rapporteurs of ENVI and ITRE as well as most of the shadow-rapporteurs during the Plenary session on 24 February 2014 gave favorable statements on the final deal. For example, the ENVI's rapporteur Thomas Ulmer from the European People's Party (EPP) group stated at the plenary on 24 February 2014 as follows:

We have also granted supercredits of 7.5 [nbsp] \% spread over three years. This means an increase in carbon dioxide of 328 [nbsp] 125 [nbsp] tonnes in the $5 \%$ control and 492 [nbsp] 188 tonnes in the range of these supercredits. In my view, this is a reasonable concession to car manufacturers. (EP 2014, English translation).

The shadow from the European Green Party Carl Schlyter from Sweden expressed a serious concern about the modalities for the $2020 \mathrm{CO}_{2}$ cap, stating as follows:

It is not at all the $95 \mathrm{~g}$ we have today. If you take into account super credits and that only 95 per cent of the fleet can be counted in 2020. Taking into account the technology development that can be additionally charged, we end up at $100 \mathrm{~g}$ in 2020 or even above" (EP 2014, English translation).

However, in Case 3, environmental discourse built on carbon neutrality and alternative technologies featured the statements at the Plenary session on 26 March 2019. The rapporteurs from ENVI and TRAN and shadow-rapporteurs from several political parties at ENVI, including S\&D, ALDE, European Green and Europe of Freedom and Direct Democracy (EFD). The representative from the European Greens Bas Eickhout welcomed the high ambition of the final compromise despite huge splits between countries over the stringency of the new policy (EP 2019). The Maltese ENVI rapporteur Miriam Dalli from S\&D emphasized in her speech that she managed to secure tight policy design toward 2030 despite strong lobbying and opposition:

the transition to a carbon-neutral economy can help address climate change, improve our health and environment, and can bring a new impulse to our countries' industrial competitiveness. ... The final $\mathrm{CO}_{2}$ reduction targets agreed upon during the trilogue negotiations for 2025 and 2030 are a step in this direction" (EP 2019).

Only a few shadows raised serious concerns about the stringency of the final compromise in their statements. Czech rapporteur Kateřina Konečná from GUE/NGL raised concerns. Konečná stated, “...the exaggerated demands on the development of new technology have passed onto the manufacturers..." (EP 2019, English translation). Finally, Italian shadow rapporteur Danilo Oscar Lancini from the Europe of Nations and Freedom (ENF) group stated, "they [new $\mathrm{CO}_{2}$ targets] do not take into account current socioeconomic technological realities and will impact heavily on the entire automotive sector chain, which employs over 12 millions of workers across Europe" (EP 2019, English translation).

These findings indicate the institutionalization and structuration of the socioeconomic discourse, which turned out to be major discourse while the environment discourse remain 
minor in Case 1 and Case 2. The replacement of this dominant discourse took place during the legislative process in Case 3 with the environment discourse gradually replacing the socioeconomic discourse. Miriam Dalli noted a gradual learning process that took place within the EP during the course of policy debates in her final statement during the 2019 Plenary session, “...Members who originally proposed less ambition today are speaking about this compromise positively, because I am convinced that it was the initial ambition of this Parliament that changed things" (EP 2019). Thus, there was a dominant discourse change behind the EU's decision in 2019 to adapt a stringent $\mathrm{CO}_{2}$ emission standard toward 2025 and 2030, which confirms the first hypothesis of this article.

\section{Change factors}

\subsection{International climate norms and EU's global climate leadership}

The EU has been playing a leadership role at global climate negotiations since the late 1980s. The climate norms, including the 1997 Kyoto Protocol and the 2015 Paris Agreement, and the strong aspirations of European policy makers to lead the negotiations by examples influenced the legislative process at the EU level exogenously. They served as a driving force for European institutions to keep its $\mathrm{CO}_{2}$ emissions standards on PCs up to date (Falkner 2007; Oberthür and Pallemaerts 2010). For example, the following statement by Miguel Arias Cañete, European Commissioner for Climate Action and Energy, stated, "Europe is once again showing how to turn the Paris Agreement and COP 24 into action" (Cañete 2018).

International climate norms and the EU's global leadership, which are exogenous to the policy-making process of EU fuel economy policy, normatively influenced the discursive battles between two competing coalitions in favor of the environment discourse coalition. It served as a glue for multiple actors with environmental interests as they formed their narratives around climate norms. They sought the basis of legitimacy to justify their claim for more stringent policy design across the three cases. The rapporteur of the ENVI Committee used the alignment with the Paris Agreement for a more ambitious $\mathrm{CO}_{2}$ target within the Parliament, stating in her report "...having the right $\mathrm{CO}_{2}$ targets for vehicles is fundamental for the shift toward the decarbonization of the economy, in line with the Paris Agreement." (EP 2018b, p. 43). Similarly, numerous Member Stated in the environment discourse coalition stated, "a raise of the ambition level, ... would be necessary in light of the national targets set out in the Effort Sharing Regulation and the objectives of the Paris Agreement" (Council 2018, p. 4).

\subsection{Declining influence of key member states}

Historical comparison observes the influence of national-level factor, particularly a declining presence of certain Member States in the socioeconomic discourse coalition, such as Germany, France, Spain, Italy and the UK. These countries played a key role to push for the socioeconomic discourse and aligned their storylines together to frame the conversations at Council meetings to secure greater flexibilities for automobile industry's $\mathrm{CO}_{2}$ compliance. Germany was particularly instrumental in pushing for automobile industry's interest as a core member of the socioeconomic discourse coalition in Case 1 and 2. However, Germany did not play as prominent a role in Case 3 as in Case 1 and Case 2. Chancellor 
Merkel, who actively pushed for socioeconomic discourse in the previous two cases, could not take decisions until October 2018, only 2 months before the final deal (Stam 2018).

Germany's declining presence during the discursive battles at the EU level related to its national and regional circumstances. Firstly, there were divided views within the government regarding the stringency of the future $\mathrm{CO}_{2}$ emissions standard. On the one hand, the environment ministry led by Minister Svenja Schulze from the Social Democratic Party of Germany (SPD) advocated for $\mathrm{CO}_{2}$ caps of $-25 \%$ by 2025 and $-50 \%$ by 2030, stating, "Transport contributes significantly to climate change. Only clean vehicles with low-damage or climate-neutral emissions belong to the future" (Deutsche Welle 2018). On the other hand, the transport minister Andreas Scheuer from the conservative Bavarian Christian Social Union (CSU) party criticized the environment ministry's position to be unrealistic and risking job security. Secondly, the Chancellor Merkel's political party, the Christian Democratic Union of Germany (CDU) and CSU, and its partner SDP, experienced a historical defeat at the regional elections in the states of Hessen and Bavaria over the green party and right-wing nationalists Alternative for Germany in October. These national and regional factors have largely constrained the German Grand Coalition, which newly started in early 2018, to create a single voice on the European $\mathrm{CO}_{2}$ emissions standard from the early stage of the debates as they did in the previous cases to defend its domestic automobile industry (Joffe 2018).

In addition, the other Member States in the socioeconomic discourse coalition have weakened their presence at policy discussions or changed their positions overtime to the environment discourse coalition. France, the UK, Spain and Italy were initially strong advocates of the socioeconomic discourse in Case 1 and Case 2, striving to frame the policy debates to advocate for greater flexibility together with Germany. The change in their positions or presence at the EU level can be associated with their domestic political situations, including governmental changes and, Brexit.. A typical example is France, who played a pivotal role in Case 1 under the Presidency of Nicola Sarkozy in pushing for industrial interests while Emmanuel Macron with his environment minister François de Rugy asking for $-40 \%$ reduction by 2030 (Vey and Guillaume 2018).

\subsection{Declining influence of automobile industry}

The historical comparison shows that the influence of automobile industry declined overtime. As one of the core members in the socioeconomic discourse coalition, the German automobile industry played a prominent role at the early stage of the $\mathrm{EU} \mathrm{CO}_{2}$ emissions standard in pushing through lower $\mathrm{CO}_{2}$ caps and greater flexibility. In Case 1, they launched lobbying activities prior to the commencement of the legislative proposal by approaching the European Commission. They advocated for an increase of the $2012 \mathrm{CO}_{2}$ cap from the original target of $120 \mathrm{~g} / \mathrm{CO}_{2}$ to $130 \mathrm{~g} / \mathrm{CO}_{2}$ by promising the implement the additional measures for impartments in fuel economy. In Case 2, it is observed that Volkswagen was able to influence the Commission's legislative proposal in Case 2 as it secured to re-introduce the super-credit systems through its channels to the then EU Energy Commissioner Günther Oettinger. In addition, German automakers, such as BMW and Daimler, actively voiced their concerns through the VDA to push German governments to reopen the Trilogue discussions to increase flexibility (Hall 2012; Stockburger 2013).

Nowack and Stemkopf (2015) confirmed these observations on the strong automobile industry's lobbying as they noted that Germany automobile industry was so powerful to delay a legally binding standard and reshape the objectives of EU's fuel economy policy. 
The public consultation that took place in 2011 also showed that almost 200 individual respondents highlighted the resistance of automobile industry to fully embrace greener technology and promote cleaner and more efficient cars. These respondents felt strong lobbying activities and influence by automobile industry over politicians (EC 2011).

Automobile makers' intensive lobbying activities were also observed in Case 3. German automobile makers channeled their socioeconomic storylines the VDA to the European Commission in advance of the launch of the legislative process. Once the procedure started, the automobile makers shifted their targeted to MEPs stressing the need to be realistic about future $\mathrm{CO}_{2}$ caps and alarming them potential risk on jobs and competitiveness (Keating 2018). What makes Case 3 different from the previous cases was the actual result of lobbying. Automobile industry has largely failed to secure the policy arrangements that they advocated for despite their massive lobbying work and strong opposition to higher standards (EP 2019; McLaughlin 2018).

What can explain this declining influence of automobile industry's lobbying? Literature explain that successful advocacy activities require several affluent lobbying resources, such as capital, information, networks and organizational credibility (e.g., Crombez 2002; Eising 2007). Given the same level of engagement of automobile industry in the legislative processes, it is reasonable to assume that their lobbying resources remained constant across the three cases except the organizational credibility, which may have affected the actual effect of their discursive activities. The Dieselgate ${ }^{5}$ took place in 2015 between Case 2 and Case 3. This Manufacturers' intentional manipulation of emission values during the tests for vehicle homologation was strongly tied with the growing recognition of discrepancy in fuel economy between declared and real-world values. It also triggered increased media and regulatory scrutiny of automobile industry as the discrepancy in values was linked to the urban air pollution in major cities with increasing number of municipalities looking for diesel bans. This declining credibility of automobile industry and their arguments among European policy-makers and consumers can be seen in a series of measures introduced in the final compromise in Case 3 with increased scrutiny over automobile industry' declaration. These measures include, among other, periodical reporting of on-board fuel consumption measurement (OBFCM) and regular conformity checks of vehicles in service on $\mathrm{CO}_{2}$ values (ISC) (T\&E 2018).

\subsection{Technological development and its influence on discourse}

The comparative analysis also detected influence of technology development on discursive battles, which can be observed from changes in the narratives used in discourses deployed by both environment and socioeconomic coalitions across the three cases. At the early stages of the European $\mathrm{CO}_{2}$ emissions standard, improvement potentials in internal combustion engines were given a prominent role to shape the Europe's future mobility together with other new technologies. For example, referring to the conventional internal combustion technologies, the Commission stated in its 2005 paper-Winning the battle against global climate change, "The possibilities for further improvement of these technologies are by no means exhausted. For instance, notwithstanding the improvements in the fuel economy of PCs in the past 30 years,

\footnotetext{
5 Some car manufacturers were found to have intentionally generated lower emission values during official tests in September 2015. These manufacturers used defeat devices, which recognized that the car was being tested and change the car's behavior to lower the emissions (EC 2019).
} 
further progress in conventional internal combustion engines and new technologies, such as (mild) hybrids and fuel cells, could lead to substantial fuel savings" (EU 2005, p. 41).

This narrative of technology-neutrality featured the debates in Case 2. Certainly, there was a growing recognition of the central role of alternative technologies in the future mobility as observed in the 2011 White Paper on Transport-Roadmap to a Single European Transport Area - referring to electric vehicles and other alternative technologies as to play a primary role in the future transport systems. However, as policy debates at the EP's Plenary Session on February 2014 show, the combustion technologies were still seen as one of the key technologies to shape the way the future system of road transport would operate given the infancy of alternative technologies. The ENVI Rapporteur Thomas Ulmer was explicit on this, stating at the Plenary on 24 February 2014, "I continue to believe in the future of the internal combustion engine, at least until the storage techniques for electricity or alternative energy sources in the passenger car sector are further developed"(EP 2014).

The influence of the evolution of alternative technologies became prominent in Case 3 . Prior to the launch of the policy-making process, the Commission's communication-European Strategy for Low-Emission mobility-launched in 2016 clearly recognized the deployment of low- and zero-emission vehicles as the central pillar of its long-term mobility strategy toward zero-emission mobility. Particularly technology development of electric vehicles marked the report that recognized it as the primary means of the future road transport replacing vehicles with internal combustion engines. The evolution of alternative technologies gave the basis of legitimacy for environment discourse coalition during the discursive battles in 2018 as they built their narratives and storylines around massive deployment of clear vehicles. This environment storyline featured the statements of rapporteurs and shadows during the plenary session in March 2019. For example, ENVI Rapporteur Miriam Dalli stated, "the new law means fuel savings for consumers and will make it affordable to buy zero- and lowemission vehicles in the years to come... Policies need to move the shift toward cleaner transport and we, as policy makers, need to encourage and stimulate this move, as I believe we'll be doing in this legislation." (EP 2019).

What was equally prominent was a declining trust in internal combustion technologies triggered by rising concerns about air pollution and the Dieselgate. Ban on diesel vehicles was introduced in major European cities, including Germany (Reuter 2018) the UK (BBC 2020) and France, which may have influenced their positioning and discursive activities at the European level in case 3 While European policy makers still kept a view that internal combustion engines would have a role in the future transport system, the evolution of alternative technologies and decreasing trust in diesel technologies weakened the basis of the legitimacy of socioeconomic discourse, which was job security and industry's competitiveness. Environment discourse coalition was conscious about the importance of considering socioeconomic aspects of the future policy design in their discursive strategies, and they framed the issue of $\mathrm{CO}_{2}$ emissions standard as a tool to create new industries and jobs with Chinese massive investment in electric vehicle technologies as an example.

\section{Conclusion and policy implications}

The research question that has guided this article was, why were European policy-makers able to set one of the world's most stringent fuel economy policies in 2019. Much of the existing literature has highlighted strong influence of automobile industry on EU policymaking processes, and has not provided a sufficient answer to this question. To fill this 
research gap, this article has drawn on the ADA and conducted a historical comparison of three legislative processes to highlight a change in dominant discourse and coalition overtime: the policy processes leading up to the adoption of the existing $\mathrm{CO}_{2}$ standards featured the hegemony of socioeconomic discourse coalition in which automobile industry's lobbying showed strong influence on policy outcomes; it was only in 2018 when environment discourse coalition took over the hegemonic status.

In addition, the perspective of the MLG inspired this article, as it sought key explanatory factors of this discourse change across different levels of governance, from international to European and national levels. It was the combination of exogenous and endogenous factors that emerged at multiple levels of governance, ranging from the evolution of international climate norms to changes in national and regional political climates, technology evolutions and falling credibility of automobile industry's lobbying. The environment discourse coalition managed to frame their narratives and storylines carefully to canalize the supportive socio-political and technological force into their discursive strategies to structure the policy conversations.

These research outcomes have several implications for the broader literature of EU policy-making and interest representation. Firstly, this article showed the argumentative nature of EU policy-making processes and the importance of discourses that shape policy debates on key energy and environmental policies. Interests, power, resources and beliefs are all important variables in most policy studies, but more attention to discourses may bring additional insights into future policy studies. secondly, this article highlighted the need of more nuanced reflections on the power of economic interests because the conventional view of the dominance of economic interests is not able to explain certain policy outcomes.

The article also confronts several limitations, which provide opportunities for further research. They include the need for a deeper insight into the parliamentary politics between political parties, more investigations on domestic situations in Germany, France, Spain, Italy and the UK, whose discursive power and influence at the EU fuel economy debates weakened overtime, and a more focused research on the impact of Dieselgate on the power of business actors, which can be observed more clearly by looking into vehicle emission testing standards. All of these would require more empirical data that can be produced through expert interviews with key decision-makers and stakeholders.

Funding Open Access funding enabled and organized by Projekt DEAL.

Open Access This article is licensed under a Creative Commons Attribution 4.0 International License, which permits use, sharing, adaptation, distribution and reproduction in any medium or format, as long as you give appropriate credit to the original author(s) and the source, provide a link to the Creative Commons licence, and indicate if changes were made. The images or other third party material in this article are included in the article's Creative Commons licence, unless indicated otherwise in a credit line to the material. If material is not included in the article's Creative Commons licence and your intended use is not permitted by statutory regulation or exceeds the permitted use, you will need to obtain permission directly from the copyright holder. To view a copy of this licence, visit http://creativecommons.org/licenses/by/4.0/.

\section{References}

Ansell, C. (2000). The networked polity: regional development in Western Europe. Governance, 13(2), 279-291. 
Bouwen, P. (2009). The European Commission. In D. Coen \& J. Richardson (Eds.), Lobbying the European Union (pp. 19-38). Oxford: Oxford University Press.

Corbett, R., Jacobs, F., \& Shackleton, M. (2011). The European Parliament (8th Revised edition). London: John Harper Publishing.

Crombez, C. (2002). Information, lobbying and the legislative process in the European Union. European Union Politics, 3(1), 7-32.

Eising, R. (2007). The access of business interests to EU Institutions: towards Elite Pluralism? Journal of European Public Policy, 14(3), 384-403.

Erbach, G. (2019). Briefing EU Legislation in Progress-CO2 Standards for new cars and vans. Brussels, Belgium: European Parliament.

Falkner, R. (2007). The political economy of 'normative power' Europe: EU environmental leadership in international biotechnology regulation. Journal of European Public Policy, 14(4), 507-526.

Fischer, F. (2003). Reframing Public Policy: Discursive Politics and Deliberative Practices. Oxford; New York: Oxford University Press.

George, A. L., \& Bennett, A. (2005). Case Studies and Theory Development in the Social Sciences. New York: MIT Press.

Haas, T., \& Sander, H. (2019). The European Car Lobby-A critical analysis of the impact of the automotive industry. Brussels, Belgium: Rosa Luxemburg Stiftung.

Hajer, M. A. (1995). The politics of environmental discourse. Oxford [u.a.]: Clarendon Press.

Hajer, M. A. (2006). Doing discourse analysis: coalitions, practices, meaning. In M. van den Brink \& T. Metze (Eds.), Netherlands Geografische Studie, 344 (pp. 65-74). Utrecht, the Netherlands: Netherlands Graduate School of Urban and Regional Research.

Heclo, H. (1974). Modern Social Politics in Britain and Sweden: From Relief to Income Maintenance. New Haven: Yale University Press.

Hooghe, L., \& Marks, G. W. (2001). Multi-level Governance and European Integration. Lanham: Rowman $\&$ Littlefield.

Howarth, D. (2002). An archaeology of political discourse? Evaluating Michel Foucault's explanation and critique of ideology. Political Studies, 50(1), 117-135.

Katzemich, N. (2018). Case study 8-Dieselgate and the German Car Industry. In Corporate capture in Europe-When big business dominates policy-making and threatens our right (pp. 88-105). Brussels, Belgium: Alliance for Lobbying Transparency and Ethics Regulation (ALTER-EU).

Kohler-Koch, B. (1997). Organized Interests in the EC and the European Parliament. European Integration Online Papaers (EIoP), 1(009).

Mahoney, J., \& Rueschemeyer, D. (2003). Comparative historical analysis: achievements and agendas. In Comparative Historical Analysis in the Social Sciences (pp. 3-38).

Mahoney, J., \& Thelen, K. (2010). A theory of gradual institutional change. In J. Mahoney \& K. Thelen (Eds.), Explaining Institutional Change-Ambiguity, Agency, and Power (pp. 1-37). Cambridge; New York: Cambridge University Press.

Moosmann, L., Urrutia, C., Siemons, A., Cames, M., \& Schneider, L. (2019). International Climate Negotiations-Issues at stake inview of the COP25 UN Climate Change Conference in Madrid (Study for the Committee on the Environment, Public Health and Food Safety of the European Parliament, Policy Department for Economic, Scientific and Quality of Life Policies). European Parliament.

Nowack, F., \& Sternkopf, B. (2015). Lobbyismus in der Verkehrspolitik: Auswirkungen der Interessenvertretung auf nationaler und europäischer Ebene vor dem Hintergrund einer nachhaltigen Verkehrsentwicklung (Working Paper No. 2015 (2)).

Oberthür, S., \& Kelly, C. R. (2008). EU leadership in international climate policy: achievements and challenges. Italian Journal of International Affairs, 43, (4), 35-50.

Oberthür, S., \& Pallemaerts, M. (2010). The EU's internal and external climate policies: An historical overview. In S. Oberthür \& M. Pallemaerts (Eds.), The New Climate Policies of the European Union (pp. 27-64). Brussels, Belgium: VUB PRESS Brussels University Press.

Pollack, M. A. (1997). Delegation, agency, and agenda setting in the European Community. International Organization, 51(1), 99-134.

Tsiakmakis, S., Fontaras, G., Cubito, C., Pavlovic, J., Anagnostopoulos, K., \& Ciuffo, B. (2017). From NEDC to WLTP: Effect on the type-approval $\mathrm{CO}_{2}$ emissions of light-duty vehicles. 


\section{Policy documents}

Cañete, M. A. (2018). Another deal!! This time on \#CO2cars. [Tweet]. Retrieved 22 December 2019, from @ mac_europa website: https://twitter.com/mac_europa/status/1074751703327612929?lang=fr

Commission of the European Communities (EC). (1995). Communication from the Commission to the Council and the European Parliament-A Community strategy to reduce $\mathrm{CO}_{2}$ emissions from passenger cars and improve fuel economy (COM (95) 689 final).

Commission of the European Communities (EC). (2005). Commission Staff Working Paper-Winning the battle against global climate change (MEMO/05/42).

Commission of the European Communities (EC). (2007a). Communication from the Commission to the European Parliament and Council-A competitive automotive regulatory framework for the 21st Century-Commission's position on the CARS 21 High Level Group Final Report-A contribution to the EU's Growth and Jobs Strategy (COM (2007) 22 final).

Commission of the European Communities (EC). (2007b). Proposal for a Regulation of the European Parliament and of the Council setting emission performance standards for new passenger cars as part of the Community's integrated approach to reduce $\mathrm{CO}_{2}$ emissions from light-duty vehicles (COM (2007) 22 final).

Commission of the European Communities (EC). (2011). Communication from the Commission to the European Parliament, the Council, the European Economic and Social Committee and the Committee of the Regions-A Roadmap for moving to a competitive low carbon economy in 2050 (COM (2011) 112 final).

Commission of the European Communities (EC). (2012). Legislative Proposal o amend Regulation (EC) $n^{\circ} 443 / 2009$ to define the modalities for reaching the 2020 target to reduce $\mathrm{CO}_{2}$ emissions from new passenger cars (COM (2012) 0393 final).

Commission of the European Communities (EC). (2017). Proposal for a Regulation of the European Parliament and of the Council setting emission performance standards for new passenger cars and for new light commercial vehicles as part of the Union's integrated approach to reduce $\mathrm{CO}_{2}$ emissions from light-duty vehicles and amending Regulation (EC) No 715/2007 (recast) (COM (2017) 676 final).

Commission of the European Communities (EC). (2019). EU actions since Dieselgate. Retrieved from https ://ec.europa.eu/docsroom/documents/34923

Council of the European Union (Council). (2008). Presidency Note (7992/08).

Commission of the European Communities (EC). (2013). Proposal for a Regulation of the European Parliament and of the Council amending Regulation (EC) No 443/2009 to define the modalities for reaching the 2020 target to reduce $\mathrm{CO}_{2}$ emissions from new passenger cars. - Analysis of the final compromise text with a view to agreement (16923/13).

Commission of the European Communities (EC). (2018). Proposal for a Regulation of the European Parliament and of the Council setting emission performance standards for new passenger cars and for new light commercial vehicles aspart of the Union's integrated approach to reduce $\mathrm{CO}_{2}$ emissions from light-duty vehicles and amending Regulation (EC) No 715/2007 (recast)-General approach (12627/18).

European Parliament (EP). (2008a). Report on the proposal for a regulation of the European Parliament and of the Council setting emission performance standards for new passenger cars as part of the Community's integrated approach to reduce $\mathrm{CO}_{2}$ emissions from light-duty vehicles (A6-0419/2008 ed.).

European Parliament (EP). (2008b). Opinion for the Committee on the Environment, Public Health and Food Safety on the proposal for a regulation of the European Parliament and of the Council setting emission performance standards for new passenger cars as part of the Community's integrated approach to reduce $\mathrm{CO}_{2}$ standards from light-duty vehicles.

European Parliament (EP). (2008c). Debates-Tuesday, 16 December 2008-Emission performance standards for new passenger cars (debate). Retrieved 8 December 2019, from https://www.europ arl.europa.eu/sides/getDoc.do?type $=$ CRE\&reference $=20081216 \&$ secondRef $=I T E M-015 \& l a n g u$ age $=$ EN\&ring $=$ A6-2008-0419

European Parliament (EP). (2013). Report on the proposal for a regulation of the European Parliament and of the Council amending Regulation (EC) No 443/2009 to define the modalities for reaching the 2020 target to reduce $\mathrm{CO}_{2}$ emissions from new passenger cars (A7-0151/2013 ed.).

European Parliament (EP). (2014). Debates-Monday, 24 February 2014-2020 target to reduce $\mathrm{CO}_{2}$ emissions from new passenger cars (debate). Retrieved 8 December 2019, from https://www.europ arl.europa.eu/sides $/$ getDoc.do type $=$ CRE\&reference $=20140224 \&$ secondRef $=$ ITEM-017\&langu age $=$ EN\&ring $=$ A7-2013-0151

European Parliament (EP). (2018a). Draft report on the proposal for a regulation of the European Parliament and of the Council setting emission performance standards for new passenger cars and for new 
light commercial vehicles as part of the Union's integrated approach to reduce $\mathrm{CO}_{2}$ emissions from light-duty vehicles and amending Regulation (EC) No 715/2007(recast).

European Parliament (EP). (2018b). Report on the proposal for a regulation of the European Parliament and of the Council setting emission performance standards for new passenger cars and for new light commercial vehicles as part of the Union's integrated approach to reduce $\mathrm{CO}_{2}$ emissions from lightduty vehicles and amending Regulation (EC) No 715/2007(recast) (A8-0287/2018 ed.).

European Parliament (EP). (2019). Debates-Emission performance standards for new passenger cars and for new light commercial vehicles (debate)—Tuesday, 26 March 2019. Retrieved 8 December 2019, from https://www.europarl.europa.eu/doceo/document/CRE-8-2019-03-26-ITM-018_EN.html

\section{Web article}

BBC News (2020, February 4). How will the petrol and diesel car ban work? 02.04.2020. Retrieved 1 September 2020, from BBC News website:https://www.bbc.com/news/uk-40726868

Deutsche Welle, D. (2018, June 6). German Environment Ministry pushes for tough $\mathrm{CO}_{2}$ cuts, electric cars | DW | 06.06.2018. Retrieved 22 December 2019, from DW.COM website: https://www.dw.com/en/ german-environment-ministry-pushes-for-tough-co2-cuts-electric-cars/a-44096346

EURACTIV. (2008a, March 4). EU governments clash on car $\mathrm{CO}_{2}$ plans. Retrieved 6 October 2019, from https://www.euractiv.com website: https://www.euractiv.com/section/transport/news/eu-government s-clash-on-car-co2-plans/

EURACTIV. (2008b, December 2). EU clinches deal on $\mathrm{CO}_{2}$ emissions from cars. Retrieved 21 December 2019, from https://www.euractiv.com website: https://www.euractiv.com/section/transport/news/euclinches-deal-on-co2-emissions-from-cars/

Hall, M. (2012, October 12). Oettinger tells Volkswagen he relaxed new $\mathrm{CO}_{2}$ targets. Retrieved 26 October 2019, from https://www.euractiv.com website: https://www.euractiv.com/section/transport/news/oetti nger-tells-volkswagen-he-relaxed-new-co2-targets/

Joffe, J. (2018, October 29). The long, painful end of Angela Merkel. Retrieved 8 December 2019, from POLITICO website: https://www.politico.eu/article/the-long-painful-end-of-germany-cdu-angela-merkel/

Keating, D. (2018, October 2). EU Sees Lobbying Frenzy Ahead Of Car $\mathrm{CO}_{2}$ Vote. Retrieved 22 December 2019, from Forbes website: https://www.forbes.com/sites/davekeating/2018/10/02/eu-prepares-for-ashowdown-on-car-co2-limits/

Mahoney, J. (2004). Comparative-historical methodology. Annual Review of Sociology, 30(1), 81-101.

Marshall, D. (2015). Explaining Explaining interest group interactions with party group members in the european parliament: Dominant party groups and coalition formation. JCMS. Journal of Common Market Studies, 53(2), 311-329.

McLaughlin, C. (2018, December 17). Auto industry reacts to deal on $\mathrm{CO}_{2}$ targets for cars and vans. Retrieved 8 December 2019, from ACEA - European Automobile Manufacturers' Association website: https://www.acea.be/press-releases/article/auto-industry-reacts-to-deal-on-co2-targe ts-for-cars-and-vans

Neslen, A. (2013, September 30). Germany proposes four-year delay to EU '95 grams' car goal. Retrieved 26 October 2019, from https://www.euractiv.com website: https://www.euractiv.com/section/transport/ news/germany-proposes-four-year-delay-to-eu-95-grams-car-goal/

Reuters. (2018, November 16). Factbox: German cities ban older diesel cars. Reuters. https://www.reute rs.com/article/us-germany-emissions-factbox-idUSKCN1NK28L

Stam, C. (2018, June 27). Berlin divided over cars' $\mathrm{CO}_{2}$ limits, hindering EU decision. Retrieved 8 December 2019, from https://www.euractiv.com website: https://www.euractiv.com/section/electric-cars/ news/berlin-divided-over-car-co2-limit-hindering-eu-decision/

Stockburger, C. (2013, December 25). Jahresrückblick 2013: Die wichtigsten Auto-Gesetze. Retrieved 26 October 2019, from Spiegel Online website: https://www.spiegel.de/auto/aktuell/co2-grenzwerte -punktereform-und-wltp-neue-gesetze-im-jahr-2013-a-940164.html

Transport \& Environment (T\&E). (2018, April). $\mathrm{CO}_{2}$ emissions from cars: The facts. Retrieved 22 December 2019, from https://www.transportenvironment.org/publications/co2-emissions-cars-facts

Vey, J.-B., \& Guillaume, G. (2018, October 4). SALON- $\mathrm{CO}_{2}$-Macron propose un donnant-donnant aux constructeurs auto. Retrieved 8 December 2019, from Investir website: https://investir.lesechos.fr/actio ns/actualites/salon-co2-macron-propose-un-donnant-donnant-aux-constructeurs-auto-1796203.php

Publisher's Note Springer Nature remains neutral with regard to jurisdictional claims in published maps and institutional affiliations. 